\title{
Service ecosystem perspective in the retail industry ${ }^{1}$
}

\author{
Marcello Sansone - Roberto Bruni - Annarita Colamatteo \\ Maria Anna Pagnanelli
}

\begin{abstract}
Purpose of the paper: This conceptual paper explains how the retail concept (latent concept) emerges as an ecosystem through the generation of institutional arrangements and, for this reason, through the evolution of specific institutions that affect the retail concept and the actors involved.

Methodology: The study is based on the Service-Dominant Logic (S-D Logic) and Viable System Approach (VSA) frameworks. The S-D Logic framework is applied in order to define institutions and institutional arrangements surrounding the ecosystem, and the VSA framework helps to explain the "emergent" nature of the ecosystem resulting from institutional arrangements.

Results: The identification of relevant institutions and institutional arrangements within the retail concept highlights the emergence of the retail concept as an ecosystem from the service perspective.

Research limitations: The proposed approach in this conceptual paper could be enriched with other theoretical perspectives and empirical explorations.

Practical implications: In the process of retail evolution, it is useful for practitioners to manage a systemic view of the retail concept following the ecosystem paradigm because it provides a framework for understanding the entangled relationships among the industrial production, agriculture, logistics, distribution and consumption sectors that integrate resources and exchange value belonging to the same retail system. They follow the shared purpose of surviving and co-creating value through different actors in the market.

Originality of the paper: The ecosystem paradigm is used to explain the latent concept of retail and to express the process of interaction among a multiplicity and variety of emerging institutions through resource integrations in the retail market.
\end{abstract}

Key words: retail concept; institution; institutional arrangement; ecosystem

\section{Introduction}

Generally, the prevalent literature concerning the retail sector has presented research on sales strategies and changes in marketing and management in line with changes in consumption (Bromley and Thomas, 1993; Wrigleyand Lowe, 1996; Wrigley and Lowe, 2002). The retail sector

1 A preliminary version of the paper was first presented to the Sinergie-SIMA 2017

Conference. The current version is the result of a redrafting carried out by the Authors after the conference, thanks to the additional comments received by reviewers. The current version is therefore original and unpublished. 
sinergie Vol. 36, N. 107, 2018

has a positive impact on employment and income generation (Basu, 1998; O'Dwyer and Ryan, 2002); it contributes with the generation of value for customers (Groves, 2001) as well as the selection of quality goods and services, and stimulates the local economy (Ilbery and Maye, 2006; Paddison and Calderwood, 2007; Smith and Sparks, 2000).

The economic impact of the retail sector on countries' economy is currently measured and inserted in the tertiary sector, with reference to the traditional division of economic activity into three main sectors: primary - extraction of raw materials and agriculture, secondary - manufacturing, and tertiary - services (Fisher, 1939; Fourastié, 1951; Wolfe, 1955). While this distinction may be useful in terms of the real economy's organization - for example to classify the position of companies in the market and to identify them in terms of specific functions, investments, and taxes sometimes it is not really applicable to marketing and management with regard to understanding actors' interactions in markets, especially in times characterized by fast communication, network relationships, and interactions - and sometimes the exchange in roles - between supply and demand.

The contribution of this conceptual work consists in asserting/arguing that the evolution of the modern retail concept involves many actors and stimulates several dynamics in markets that cannot be represented by the aforementioned traditional division between sectors. It is difficult to describe the modern retail concept - and especially its focus on the system of large-scale retail trade - within the framework of an economic sector (Sansone et al., 2017) in the tertiary sector, to give an example. Here, the modern retail sector is emerging as a meta-sector where companies in industrial production, agriculture, logistics, and distribution belong to the retail concept because they are included in the retail system, integrating resources and exchanging value - which involves and stimulates every actor in the market, from the production of raw material to services, and from the innovation of the supply to the stimulation - and sometimes evolution - of the demand.

The retail evolution and the interaction between supply and demand represent relevant research branches but little has actually been studied about the identification of retail in economic contexts (Betrand and Kramarz, 2002; Griffith and Harmgart, 2008), and previous research has focused more on identifying the innovation of retail in terms of management (Fernie and Sparks, 2014), marketing (Lugli and Pellegrini, 2002), private label (Batra and Sinha, 2000), and relationships between manufacturer and retailer (Varaldo and Dalli, 2011; Villas-Boas, 2007). Retail literature has focused on the management of retail companies and the relationships between customers and retailers (Sivadas and BakerPrewitt, 2000).

In order to study retail in the economic context, and to explain the retail concept as a meta-sector that identifies shared rules, languages, cultural norms, values, codes, and their interactions, the ecosystem paradigm, building on the Service-Dominant (S-D) Logic (Vargo and Lusch, 2004; 2008; 2016) and Viable System Approach (VSA) frameworks (Barile, 2009; Barile and Saviano, 2011) are used in the present study. S-D Logic concepts 
are applied in order to define institutions and institutional arrangements (Giddens, 1984; Siltaloppi et al., 2016, Vargo and Lusch, 2016) within the ecosystem, while the VSA is applied in order to distinguish the concept of an emergent ecosystem from institutional arrangements.

This study explains how it is possible to use the ecosystemic framework to understand relations and interactions (as well as future perspectives) in the modern retail concept by observing institutional arrangements shaped by the actors' interactions, changes in consumption, companies' evolution, and technology's relevant role in human life.

As a result, the paper defines emerging institutions in the retail sector and presents a hypothesis about the institutional arrangement that is most useful to attain a systemic view of the retail concept and understanding relations and interactions between the actors that are involved in the retail market, through the ecosystem approach.

The article is organized as follows. First, the methodology is presented. Second, the theoretical background of the topic is identified, presenting the emergence of the modern retail concept and theoretical background regarding VSA and S-D Logic studies. The article closes with a presentation of the retail concept as an ecosystem, followed by conclusions and managerial implications.

\section{Methodology}

This conceptual paper integrates the literature regarding the retail concept, by explaining retail contextualization in the economic scenario from VSA and S-D Logic perspectives. In order to introduce the retail concept as an emergent ecosystem, the literature is presented and the findings of the work are drawn up by modulating the various concepts emerging from the results and definitions stemming from retail literature, as well as the theoretical concepts coming from VSA and S-D Logic streams.

In the literature groundwork of this study, different approaches and contributions are presented. In particular, a brief literature review on the evolution of studies regarding the retail concept is useful to understand relevant perspectives in studies identifying the modern retail concept within a systemic view of companies in the fields of industrial production, agriculture, logistics, and distribution that integrate resources and indirectly provide value to customers. The theoretical frameworks of the Viable System Approach and S-D Logic are briefly presented; in particular, the former - VSA - is presented to highlight the role of system thinking in the definition of the structure-system dichotomy and the concept of emerging systems that will be interpreted to express the emerging ecosystem. The S-D Logic framework is followed by the identification of the roots of institutions and institutional arrangements in the ecosystem's definition.

Institutions and institutional arrangements in the retail concept are presented by modelling from the S-D Logic literature, and the emerging ecosystem is supported by the VSA framework. 
Sinergie

Vol. 36, N. 107, 2018

\section{Theoretical frameworks}

\subsection{The evolution of studies on retail and the emergence of the modern retail concept}

The literature on retail is mainly made up of studies on the sales strategies of retailers and their changes in response to changes in the context (Bromley and Thomas, 1993; Wrigley and Lowe, 1996; Wrigley and Lowe, 2002). A particular research stream studies the role of retail in the customer purchasing process with a focus on supply customisation in line with changes in consumption and lifestyle (De Kervenoael et al., 2006; Woodliffe, 2004). Retail manages the value proposition by modelling the supply in line with consumer targets, specific services, and customer interaction (Groves, 2001).

Various contributions present modern retail as an emergent concept that tries to express the emergent complexity of a meta-sector that affects a multiplicity of different actors in the economic systems of various countries (Barile and Pastore, 2002; Saviano and Caputo, 2013). Because of its specific characteristics and impact on the economy, the retail sector is affected by stimuli coming from macro and micro environments. For this reason, the economic crisis, changes in consumption, and innovation in management and organization have led to effects from different perspectives - industrial production, agriculture, consumption, new technologies - in the retail sector. Most reactive companies in the retail sector - in particular in large scale retail trade - are giving impulses to markets, stimulating, and providing innovation (Pantano, 2014).

The instability and changes in consumption might contribute to innovation and the updating of business models (Castaldo, 2008; Fornari, 2009; Lugli, 2009), in particular concerning the adaptation of companies to the environment (Pastore et al., 2001), stimulating resource integration and value exchange. The critical success factors of the past are therefore no longer applicable by retail management. For the retail industry, retail requires a new paradigm with two key strategic factors: service and technology (Kandampully, 2012).

Large scale retail trade is a representation of the dynamism of the retail system in the world and it reacts to the stimuli of the environment in different ways, adapting formats, concepts, marketing, and management approaches (Sansone et al., 2017; Bruni, 2014). Those results represent the reaction to macro and micro environmental changes and the codefinition of shared rules, languages, cultural norms, values, codes, and their interactions. Therefore, a change in perspective and a new approach to retail service marketing using a service view is necessary (Barile and Saviano, 2014).

\subsection{The Viable System Approach (VSA) and SD-Logic}

An important role in the scientific literature concerning marketing and management has been assumed by System thinking whose conceptual roots stemmed from the research of Barnard (1938; Buckley, 1967, 1968, 2008; Emery, 1969; Jackson, 2000). Over time, these studies have been enriched 
through the contributions of biologists (Maturana and Varela, 1975), ecologists (Hannan and Freeman, 1977), sociologists, and psychologists (Clark, 1993). Von Bertalanffy (1968) developed a general systems theory as a new epistemological and methodological approach to science.

The viable system model and the viable system approach represent two relevant models that view organization relationships as a system, especially with regard to management. The former starts from the work of Beer (1972) and continues with studies about management (Espejo et al., 1989; Kast and Rosenzweig, 1972) by focusing on organizations that are viable and capable of evolving, and the parts of their physical, natural, and social environments that they interact with. The latter consists in the VSA (Barile, 2009), which has similar roots in the general system theory but focuses its attention on the role of decision makers as constructors of the observed reality, subjectivism in management, differentiation between structure and system (Barile and Saviano, 2011), and on the concept of consonance and resonance in system relationships. The dichotomy structure system proposes that every system represents a recognizable entity emerging from a specific changing structure - a set of individual elements with assigned roles, activities, and tasks performing in compliance with given rules and constraints. This is relevant in looking for the next identification of the retail ecosystem, building on the SD- Logic framework.

Evolving research in marketing and management is going beyond the traditional approach to companies by explaining markets dynamics, complexity, the concept of value, and the dynamic of relationships. The trend, in particular within Service Sciences, is to deepen knowledge about the role of actors in markets, relationships, competences, and value. In particular, the switch between traditional management and the new service management approach may be understood through SD-Logic studies.

SD-Logic is based on 11 foundational premises (FPs) and five axioms (Vargo and Lusch, 2016), in which service is considered an application of competences through activities, processes, and performances that are designed to realize benefits for suppliers and customers, and for third parties that are involved in a network of relationships. In focusing on resources integration and on value exchange, the necessity to go beyond the relationship between company and customer in a dyadic relation encourages a change in approach and the consideration that value cannot come from only one source, but rather depends on the interactions of a network of actors. Within this service exchange, actors interact with other actors and with the environment because otherwise it would be impossible to realize a complete co-creative experience. Over the past years, the SDLogic approach has affected many applications and perspectives - from technology to systems, from customers' relationships to markets, and many research branches, all applying the SD-Logic approach - but the concepts of institution, institutional arrangements, and ecosystems are presented in this study.

The structuration theory presented by Giddens (1984) provided a practical approach to study value co-creation and value in context (Edvardsson et al., 2011). It is based on the constitution of social systems through practices or routines (Schatzki, 1996). As per Giddens (1984),
Marcello Sansone

Roberto Bruni

Annarita Colamatteo

Maria Anna Pagnanelli

Service ecosystem

perspective in the retail industry 
sinergie Vol. 36, N. 107, 2018

social systems are dually represented by structures (resources and rules) and systems (relationships) that are interdependent but led by practices.

That structuration theory is useful to highlight the role of institutions in resource integration and value co-creation. Giddens (1984) in particular argued that human actions influence and are influenced by standards and norms that are associated within a specific social system. Siltaloppi et al. (2016) argued that institutions consist of formalized rules, "such as laws, more informal norms including social expectations, values and moral codes that define appropriate behavior, and cultural meanings including cognitive frame and schemes that encapsulate the assumptions and beliefs fundamental to make life comprehensible". This is in line with the SD-Logic assumptions about institutional arrangements as interrelated institutions (Vargo and Lusch, 2016) that exist thanks to collective action. Institutions are not symbolic structures that govern humans, but are instantiated in social practices and preserved and modified by human behavior (Geertz, 1973; Scott, 2014).

Resources integration and value exchange exist in contexts that are able to stimulate the continuous interrelation of institutions - institutional arrangements - and the emergence of the ecosystem. This concept arises from the consideration of the actors as resource integrators through the application of competences that co-create value for others and for themselves (Vargo and Lusch 2008). From such a perspective, it is impossible for an actor to create value alone; for this reason, value comes from a network of service exchanges that could be explained from a service ecosystem perspective. Service ecosystems are defined as "relatively selfcontained, self-adjusting systems of resource-integrating actors connected by shared institutional arrangements and mutual value creation through service exchange" (Vargo and Lusch 2016, pp. 10-11). S-D logic considers all social and economic actors as resource integrators and participants in value cocreation, and the ecosystemic view also strongly emphasizes institutions. It is the same for Spoher and Maglio (2010), who sustained the relevance of socially constructed meaning in service systems and highlighted the role of symbols in relation to internal behavior and other external entities.

Barile et al. (2016) efficaciously identify the integration among service, network and the ecosystem concept. They underline the basic elements of service systems, which represent the roots of relationships and interaction: knowledge, business and society, technology and culture. Service networks demand different kinds of skills and capabilities and different configurations of knowledge that have significant influence on the way service networks form and change; moreover, relationships within the network service system are relevant, and these in general reflect the nature of their service networks and the intensity with which innovations spread; technology is a key source of capabilities for service systems and institutional generation, because it provides an infrastructure network for linking service systems and achieving profitability rapidly. Finally, the relevant role of culture can accelerate or inhibit the spreading of ideas and affect the way service networks form and change.

In this study, building on the concepts of institutions and institutional arrangements and considering the structure-system dichotomy, the service 
ecosystem is proposed as a framework used to define the emergence of the retail concept. Institutions and emerging institutional arrangements in the retail context are presented below.

\section{The emergence of retail as an ecosystem}

A system could be interpreted in the VSA framework as "something that emerges" (Barile, 2009) within the shared final purpose of the elements inside; the interacting elements are connected with their will to survive in the system and within the environment. In the case of "survival", for example, it is possible to assert that the emergence of a general behavior of a system is the search for a specific purpose to survive over time that extends beyond the specific reality and belongs to more general systems. It is probable that the "emerging" nature of a system is either caused by the will of the government body or by the will of actors to integrate their resources. The real necessity of "survival" probably belongs to the systems in which each subsystem/agent/actor is part of a whole, and the whole, over time, will appear as a system when every element contributes to its survival. The feature of survival could surely be pursued by a decision maker. The decision maker - the government body - needs to lead the system toward survival.

The concept of the emerging system is at the base of this study in its attempt to describe the dynamic of relationships among actors in the configuration of the ecosystem that identifies the retail concept. To complete the configuration of the ecosystem Barile et al. (2016) support the proposal to use basic elements of service systems that represent the roots of relationships and interaction - knowledge, business and society, technology and culture. The S-D Logic approach supports the necessity to consider institutions such as formalized rules "such as laws, more informal norms including social expectations, values and moral codes that define appropriate behavior, and cultural meanings, including cognitive frames and schemas, that encapsulate the assumptions and beliefs fundamental to make life comprehensible" (Siltaloppi et al., 2016) and institutional arrangements, i.e. a set of interrelated institutions; the role and process of institutionalization are the keys to understanding the structure and functioning of the service ecosystem - as contributions to the emergence of the ecosystem. The VSA supports the S-D Logic framework in defining ecosystems through consonance and resonance concepts. These two concepts help to explain that resource integration is the result of both a structural compatibility (consonance) and the will to share a final purpose in the actors interaction (resonance). The actors interact in the medium and long run thanks to their will to share (and achieve) a final (and satisfying) purpose. VSA contributes to S-D Logic by explaining the reason why the actors are stimulated by interaction; in particular, it explains the basic need to share a purpose to survive in interaction (through resonance). The shared final purpose is the stimulus to seek to understand the emerging of institutional arrangements. The merging of the two - VSA and S-D Logic - approaches is useful in selecting the institutions and institutional arrangements that affect the retail concept in the actual economic scenario. 


\section{sinergie}

Vol. 36, N. 107, 2018

\subsection{Institutions in the retail concept}

Considering the characteristics of the modern retail concept, it is possible to define a system of institutions that affect relationships among actors in the retail system. Considering the relevance of consumption, the turbulence of the market, the evolution of the relationships among manufacturers and retailers, the evolution of technology, and, as presented above, the possible roots of relationships and interactions - knowledge, business and society, technology and culture - (Barile, 2016) it is possible to configure some institutions that affect the dynamic of relationships between actors in the retail system. In Table 1, it is possible to find the selection that will contribute to the emergence of relevant institutional arrangements.

Tab. 1: The configuration of institutions in the retail concept

\begin{tabular}{|c|c|c|}
\hline & $\begin{array}{l}\text { Institutions } \\
\text { in the retail concept }\end{array}$ & Meaning \\
\hline \multirow[t]{6}{*}{$\begin{array}{l}\text { Modern } \\
\text { retail } \\
\text { concept }\end{array}$} & $\begin{array}{l}\text { Organizing the value } \\
\text { proposition in store for } \\
\text { customers }\end{array}$ & $\begin{array}{l}\text { The traditional institution that permits the identification of the retail } \\
\text { industry's mission. }\end{array}$ \\
\hline & $\begin{array}{l}\text { Mobile applications for } \\
\text { ordering services and offers }\end{array}$ & $\begin{array}{l}\text { The spread of the use of mobile phones affects the various } \\
\text { stakeholders that are working in distribution on a daily basis. The } \\
\text { rules surrounding mobile applications are shared by a multiplicity } \\
\text { of actors - stakeholders - that are working in the retail sector. The } \\
\text { institution of mobile applications affects both supply and demand. }\end{array}$ \\
\hline & $\begin{array}{l}\text { Relationships between } \\
\text { manufacturer and retailer }\end{array}$ & $\begin{array}{l}\text { Twenty years ago, relationships between manufacturers and retailers } \\
\text { represented a particularly competitive advantage for retailers. Today, } \\
\text { languages, agreements, and managerial figures - e.g. the trade } \\
\text { marketing manager - represent a shared institution at the base of the } \\
\text { competitive advantage. }\end{array}$ \\
\hline & Private label as a strategic asset & $\begin{array}{l}\text { Much of today's literature is presents the concept of private labels; } \\
\text { scholars and practitioners are debating the strategic role of this asset } \\
\text { that goes beyond its mere use as a tool to increase margins and profit. } \\
\text { Today, the private label is a shared language and code that affects } \\
\text { supply (retailers), production, and demand (customers). }\end{array}$ \\
\hline & Accepted logistics practices & $\begin{array}{l}\text { Technology and the evolution of communication bring a lot of } \\
\text { innovation in logistics practices that create shared languages in } \\
\text { extended supply networks. Such logistics practices represent a core } \\
\text { activity that involves numerous actors, and for this reason many } \\
\text { codes are shared. }\end{array}$ \\
\hline & $\begin{array}{l}\text { Mobile communication and } \\
\text { data exchange }\end{array}$ & $\begin{array}{l}\text { Demand and supply share habits regarding mobile communication. } \\
\text { For this reason, this institution is considered as a normal driver } \\
\text { to control and manage. The rules and constraints of mobile } \\
\text { communication enable an increase in opportunities to connect the } \\
\text { value network by considering this tool as a fundamental element of } \\
\text { competitive advantage and not as a residual accessory. }\end{array}$ \\
\hline & E-commerce and rating systems & $\begin{array}{l}\text { They represent a new language and a basic institution with specific } \\
\text { rules and goals. It is not substituting traditional retail but, if well } \\
\text { used, it may integrate retailers' value proposition by completing the } \\
\text { supply and integrating marketing and communication. In particular, } \\
\text { e-commerce improves the sales of retailers and suppliers and rating } \\
\text { systems stimulate shared measures of reliability. }\end{array}$ \\
\hline & Sharing solutions & $\begin{array}{l}\text { Sharing solutions affect the entire world and the economy in this } \\
\text { period. In the retail system, the most relevant example of sharing } \\
\text { solution is the distribution center shared among several different } \\
\text { retailers, including competitors. }\end{array}$ \\
\hline & $\begin{array}{l}\text { Dynamic and hybrid formats } \\
\text { and concepts }\end{array}$ & $\begin{array}{l}\text { The system of stakeholders in the retail system - from manufacturer } \\
\text { to distribution - shares the necessity to apply a dynamic innovation } \\
\text { as a shared and cultural behavior among actors. The concept of } \\
\text { continuous adaptation leads retailers to diversify the supply and } \\
\text { integrate new and different services into the value proposition. } \\
\text { This is possible when the system shares the concept of dynamic } \\
\text { innovation. }\end{array}$ \\
\hline
\end{tabular}

Source: Authors' elaboration 
In Fig. 1 below, it is possible to view the systems of institutions surrounding the modern retail concept and contributing to developing institutional arrangements in the emergence of the retail concept as an ecosystem. The explained institutions - as well as future ones - will contribute to defining the modern retail concept that will merge their effects, identifying the nature and shapes of modern retail as an ecosystem. The interrelation of the institutions - i.e institutional arrangements will contribute to defining the structure and functioning of the service ecosystem. It is therefore useful to interpret the trends and roles of every actor in the ecosystem.

Fig. 1: The system of institutions surrounding the Modern Retail Concept: towards a definition of institutional arrangements

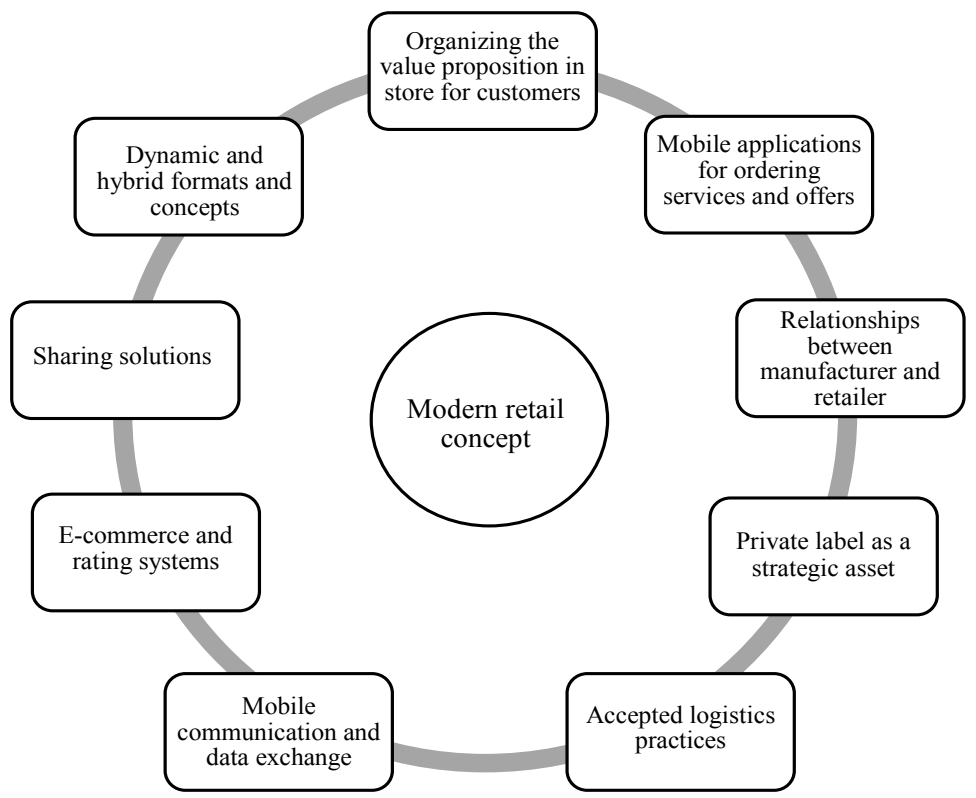

Source: Authors' elaboration

\subsection{The emergence of the retail concept as an ecosystem}

In the process of describing the emerging ecosystem through the retail concept it is useful to analyze three levels of interpretation (Vargo and Lusch, 2016), starting from the micro level, then moving to the meso-level, and then, upon achieving the ecosystem status, identifying (the macrolevel) the third level. In general, the micro-level of analysis represents service exchange - resource integration and value exchange between two actors - the second level - the meso-level - represents the system of service exchanges in which different service exchanges identify a network of service systems and institutions. The third level - the macro-level -, emerging through the combination of different institutions characterized by institutional arrangements represents the ecosystem (Fig. 2). 


\section{sinergie}

Vol. 36, N. 107, 2018
Fig. 2: Three layers/levels moving towards the ecosystem

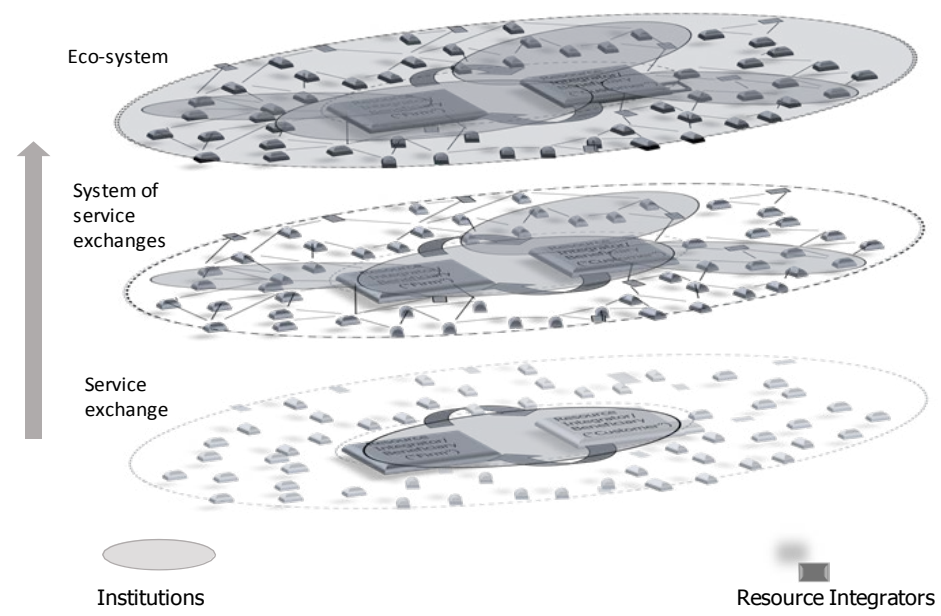

Source: Vargo, 2016

It is possible to express the path towards the emerging ecosystem through the retail concept by interpreting each layer/level of the three steps. The first - the micro-level -represents the retailer and his fundamental activity as an individual actor that interacts with the customer in his attempt to survive over time. An analysis into relationships among actors - i.e. in general, the retail company and customer (or supplier) - is needed. The simple level of analysis only considers value co-creation and the relevance of activated relations, and for this reason these interactions are relevant. The second layer moving towards the ecosystem is the network of retailers. It is represented by a network of individual chains or individual organizations that share technology, knowledge, and culture in order to achieve common goals (VSA and the resonance concept). They focus their businesses on searching for competitive advantages based on cost reduction, revenues, and the optimization of relationships with revenues as their principal goal. There is no effort to create an institutionalization of relationships and resources integration among actors from different sectors. In the third level, the ecosystem emerges thanks to the shared path towards institutional arrangements in the emergence of a viable system (Barile, 2016). The retail concept emerges with purity because no government bodies are presented, and the aggregation of the actors starts from the institutional arrangements that are automatically generated by the evolution of relationships. Each actor has the opportunity to interact thanks to structural compatibility (consonance - Barile, 2009) and the will to achieve one's own final purpose (he survival), which is the same as that of other actors who are involved in the retail context (resonance - Barile, 2009). The ecosystem emerges from motivated interactions that are stimulated by the dynamic of institutional arrangements. This kind of evolution might also lead the ecosystem to collapse, possibly changing the nature and role of the retail concept or, certainly, contributing to its 
innovation and evolution (Boehm and Hogan, 2013; Arikka-Stenroos et al. 2014). The retail ecosystem emerges as being characterized by interactive service systems that include interactions among humans and non-humans; in the latter case, the non-human contribution is represented by the role of service system platforms - automatic systems for data and information management.

These considerations give rise to the need to consider the retail concept as a dynamic phenomenon and the opportunity to interpret retail as an ecosystem. The defining of basic institutions in retail concept can reduce the complexity of understanding future trends in retail concept evolution. In particular, as concerns the competition/integration of online and offline retail activity, basic retail institutions could favor their understanding. Of course, identifying the retail concept as an ecosystem is an effort that helps to understand differences with other study paradigms (marketing vertical systems, supply chain management and other technical analyses applied to measure costs, revenues, profits, relationship intensity, etc.). The ecosystem emerges to the observer who is interested in studying the system dynamics of actor interaction in the retail system by observing institutional relationships and the final (and shared) purpose of the involved actors. The ecosystem does not have the goal of quantitatively measuring the effects of interactions, and for this reason the main goal of the ecosystem is to try to explain the system of interaction, their sources and, eventually, try to predict the future and the evolving trend of institutional arrangements. These considerations could bring the observer to go beyond traditional economic sectors, thus considering retail as a relevant concept in economic dynamics analysis.

\section{Implications and conclusions}

\subsection{Conclusions}

This study explains how the retail concept emerges as an ecosystem through institutional arrangements and, for this reason, through the evolution and integration of specific institutions that affect the retail industry and the involved actors. The concept of retail and its evolution could be explained through the ecosystemic approach following the S-D Logic and VSA frameworks. In particular, with the relevance of actors' integration and the increasing role of each actor (companies or customers) in evolving tendencies, consumptions and innovations, researchers and practitioners need new approaches to understand what is happening in markets and how to manage interactions within markets' fast growing complexity. The classical economic sectors should probably be revisited and new clusters (or approaches) should be identified to understand the market relationships of the future.

The main contribution of this study is represented by the definition of some relevant institutions that can describe what the retail concept represents and how it can emerge as ecosystem in this period. The institutions that currently form the retail as an ecosystem might change or even disappear. This evolution may not necessarily be attributed directly to 
sinergie Vol. 36, N. 107, 2018

retail, rather it might be the result of a synergistic relationship stimulated by random inputs that can produce unpredictable outcomes. Although we cannot accurately predict the evolution of the ecosystem, we can imagine possible trends, analyzing not individual actors but rather the relationships among them and their capability of adapting to the external environment; the present reflections are enriched by a hypothesis about institutional arrangement configuration that was developed considering the current market, with a specific focus on the principal macro-environment represented by the average economic situation in Europe.

\subsection{Implications}

In the process of retail evolution, it is useful for practitioners to manage a systemic view of the retail concept following the ecosystem paradigm because it provides a framework for understanding relationships among manufacturers, the sectors of agriculture, logistics, distribution, and consumers that integrate resources and exchange value belonging to the same retail system; the significance of the analysis of the dynamics of these relationships emerges as a key point to forecast the evolution of each actor in the system and potential effects on consumption. The subjects involved in the retail ecosystem follow the shared purpose of co-creating value through different actors in the market. In particular, each actor who was involved in the ecosystem should be encouraged to share the final purpose of the ecosystem, and this implies that actors should increase their capabilities to share mutual benefits; the actors who acknowledge belonging to the ecosystem should sometimes reduce their direct returns to share and permit the achievement of the ecosystem's final purpose.

\subsection{Limits and future perspectives}

It is necessary to deepen the research in order to better explain the emergence of the ecosystem and the genesis of the combination of several institutions that define institutional arrangements in the service ecosystem. In any case this conceptual work represents a first step in forthcoming studies about the retail concept as an ecosystem because system thinking asserts that relationships and interactions among actors must be studied in a dynamic way and cannot be defined in a specific time or place. By deepening the research, different actors could find new definitions and the actors' new roles in the ecosystem could also be explained through the interpretation of forecasts. This research stream could affect the entire value network of distribution and of relationships between manufacturers and retailers; moreover, it could be particularly useful in interpreting the new trend of integration between physical retailers and e-commerce.

Further research is suggested with the aim of deepening the knowledge and examining the dynamic of interactions among ecosystem entities in depth, especially through the use of actantial models (Greimas, 1966), thus favoring research models with narrative approaches. In this sense, the qualitative perspective could be more effective than the quantitative one, considering the necessity to study interactional dynamics. 
A further research trend could aim ay analyzing the role of dynamic capabilities in the ecosystems because we suppose that dynamic capabilities - interpreted as the capabilities to adapt, integrate, and reconfigure internal and external organizational skills, resources, and functional competences could contribute to the single - self-adjusting, institutional configurations, resource integration and relatively self-contained - features of ecosystems and could have a relevant effect on the actors who are involved in an ecosystem and on its evolution over time.

\section{References}

AARIKKA-STENROOS L., SANDBERG B., LEHTIMÄKI T. (2014), "Networks for the commercialization of innovations: a review of how divergent network actors contribute", Industrial Marketing Management, vol. 43, n. 3, pp. 365-381.

BARILE S., PASTORE A. (2002), "Forme, caratteri e divenire sistemico dei rapporti con la distribuzione ed il consumo", in Golinelli G.M., Lapproccio sistemico al governo dell'impresa. Valorizzazione delle capacità, rapporti intersistemici e rischio nell'azione di governo, 3 , Cedam, Padova.

BARILE S. (2008), L'impresa come sistema. Contributi sullapproccio sistemico vitale, Giappichelli, Torino.

BARILE S. (2009), Management sistemico vitale (vol. 1), Giappichelli, Torino.

BARILE S., POLESE F. (2010), "Linking the viable system and many-to-many network approaches to service-dominant logic and service science", International Journal of Quality and Service Science, vol. 2, n. 1, pp. 23-42.

BARILE S., POLESE F. (2010), "Smart service systems and viable service systems: applying systems theory to service science”, Service Science, vol. 2, n. 1-2, pp. 21-40.

BARILE S., SAVIANO M. (2011), "Foundations of systems thinking: the structuresystem paradigm", in Various Authors, Contributions to Theoretical and Practical Advances in Management. A Viable Systems Approach ( $v \mathrm{Sa})$, International Printing, Avellino.

BARILE S., PELS J., POLESE F., SAVIANO M. (2012), "An introduction to the viable Systems approach and its contribution to marketing", Journal of Business Marketing Management, vol. 2, n. 2, pp. 54-78.

BARILE S., SAVIANO M., POLESE F., DI NAUTA P. (2012), "Reflections on service systems boundaries: a viable systems perspective. The case of the London Borough of Sutton", European Management Journal, vol. 30, n. 5, pp. 451-465.

BARILE S., SAVIANO M. (2014), "A new systems perspective in retail service marketing", in Handbook of Research on Retailer-Consumer Relationship Development, IGI Global.(pp. 197-218).

BARILE S., LUSCH R., REYNOSO J., SAVIANO M., SPOHRER J. (2016), "Systems, networks, and ecosystems in service research", Journal of Service Management, vol. 2, n. 4, pp. 652-674.

BARNARD C.I. (1938), The Functions of the executive, Harvard University Press, Cambridge, MA.

BASU A. (1998), "An exploration of entrepreneurial activity among Asian small businesses in Britain", Small Business Economics, vol. 10, n. 4. 
sinergie Vol. 36, N. 107, 2018

BATRA R., SINHA I. (2000), "Consumer-level factors moderating the success of private label brands", Journal of Retailing, vol. 76, n. 2, pp. 175-191.

BEER S. (1972), Brain of the firm, The Penguin Press, London.

BETRAND M., KRAMARZ F. (2002), "Does entry regulation hinder job creation? Evidence from the French retail industry", Quarterly Journal of Economics, vol. 117, n. 4, pp. 1369-1414.

BOEHM D.N., HOGAN T. (2013), "Science-to-business collaborations: A science-tobusiness marketing perspective on scientific knowledge commercialization", Industrial Marketing Management, vol. 42, n. 4, 564-579.

BROMLEY R.D.F., THOMAS C.J. (1993), Retail change: contemporary issues, Routledge, London.

BRUNI R. (2014), Dinamiche impresa-contesto-cliente e retail di prossimità, Aracne, Roma.

BUCKLEY W. (1967), Sociology and modern systems theory, Englewood Cliffs, Prentice Hall, NJ.

BUCKLEY W. (1968), Modern systems research for the behavioural scientist, Aldine Transaction, Chicago, IL.

BUCKLEY W. (2008), "Society as a complex adaptative system", Emergence: Complexity and Organization, vol. 10, n. 3, pp. 86-110.

CASTALDO S. (2008), (a cura di), Retail e channel management, Egea, Milano.

CLARK A. (1993), Associative engines, MIT Press, Boston, MA.

DE KERVENOAEL R., HALLSWORTH A. CLARKE. I. (2006), "Macro-level change and micro level effects: a twenty-year perspective on changing grocery shopping behaviour in Britain", Journal of Retailing and Consumer Services, vol. 13, n. 6, pp. 381-92.

EDVARDSSON B., TRONVOLL B., GRUBER T. (2011), "Expanding understanding of service exchange and value co-creation: a social construction approach", Journal of the Academy of Marketing Science, vol. 39, n.2, pp. 327-339.

EMERY F. (ED.) (1969), Systems thinking, Penguin Books, Harmondsworth.

ESPEJO R., HARNDEN R. (1989), The viable system model: interpretations and applications of Stafford Beer's VSM, Wiley.

FERNIE J., SPARKS L. (2014), Logistics and retail management: emerging issues and new challenges in the retail supply chain, Kogan Page Publishers, London.

FISHER A.G. (1939), "Production, primary, secondary and tertiary", Economic Record, vol. 15, n. 1, pp. 24-38.

FORNARI D. (2009), Tendenze distributive. Le nuove sfide del marketing di filiera, Egea, Milano.

FOURASTIÉ J. (1951), "Productivity and Economics", Political Science Quarterly, vol. 66, n. 2, pp. 216-225.

GEERTZ C. (1973), The interpretation of cultures, Basic Books, New York.

GIDDENS, A. (1984), The constitution of society: Outline of the theory of structuration, University of California Press.

GOLINELLI G.M. (2000), L'approccio sistemico al governo dell'impresa. L'impresa sistema vitale, 1st ed., Cedam, Padova.

GREIMAS A.J. (1966), "Eléments pour unethéorie de l'interprétation du récitmythique", Communications, vol. 8, n. 1, pp. 28-59.

GROVES A.M. (2001), "Authentic British food products: a review of consumer perceptions", International Journal of Consumer Studies, vol. 25, n. 3, pp. 246-54. 
GRIFFITH R., HARMGART H. (2008), "Supermarkets and planning regulation", CEPR Working Paper, n. 6713.

HANNAN M.T., FREEMAN J. (1977), “The population ecology of organizations”, American Journal of Sociology, vol. 82, n. 5, pp. 929-964.

JACKSON M.C. (2000), Systems approaches to management, Springer Science and Business Media, New York, NY.

KANDAMPULLY, J. (2012), Service as the new paradigm in retailing, Service Management, Springer, New York, NY, pp.1-6

KAST F.E., ROSENZWEIG J.E. (1972), "General systems theory: application for organizations and management”, Academy of Management Journal, vol. 15, n. 4, pp. 447-465.

ILBERY B., MAYE D. (2006), "Retailing local food in the Scottish-English borders: a supply chain perspective", Geoforum, vol. 37, n. 3, pp. 352-367.

LUGLI G. (2009), Marketing distributivo. La creazione di valore nella distribuzione specializzata, UTET, Torino.

LUGLI G., PELLEGRINI L. (2002), Marketing distributivo, UTET, Torino.

MATURANA H.R., VARELA F. (1975), "Autopoietic systems", Report BCL, vol. 9, n. 4, pp. 37-48.

O'DWYER M.L., RYAN E. (2002), “Management development - a model for retail business", Journal of European Industrial Training, vol. 26, n. 9, pp. 420-29.

PANTANO E. (2014), "Innovation drivers in retail industry", International Journal of Information Management, vol. 34, n. 3, pp. 344-350.

PADDISON A., CALDERWOOD E. (2007), "Rural retailing: a sector in decline?", International Journal of Retail and Distribution Management, vol. 35, n. 2, pp. 136-55.

PASTORE A., PELLEGRINI L., RAVAZZONI R. (2001), "La dimensione settoriale dell'innovazione: la distribuzione commerciale", Sinergie, n. 55, pp. 85-122.

SANSONE M., BRUNI R., COLAMATTEO A., PAGNANELLI M.A. (2017), "Dynamic capabilities in retailers' marketing strategies: defining an analysis model", Mercati and Competitività, vol. 2, pp. 17-42.

SAVIANO M., CAPUTO F. (2013), "Managerial choices between systems, knowledge and viability", in Barile S. (Ed.), Contributions to Theoretical and Practical Advances in Management. A Viable Systems Approach (VSA), vol. 2, Aracne, Roma, pp. 219-242.

SCHATZI T.R. (1996), Social practices: a Wittgensteinian approach to human activity and the social, Cambridge University Press.

SCOTT W.R. (2014), Institutions and organizations: ideas, interests and identities, Sage, Thousand Oaks, CA.

SILTALOPPI J., KOSKELA-HUOTARI K., VARGO S.L. (2016), "Institutional complexity as a driver for innovation in service ecosystems", Service Science, vol. 8, n. 3, pp. 333-343.

SIVADAS E., BAKER-PREWITT J.L. (2000), "An examination of the relationship between service quality, customer satisfaction, and store loyalty", International Journal of Retail and Distribution Management, vol. 28, n. 2, pp. 73-82.

SMITH A., SPARKS L. (2000), "The independent small shop in Scotland: a discussion of roles and problems”, Scottish Geographical Journal, vol. 116, n. 1, pp. 41-58.

SPOHRER J.C., MAGLIO P.P. (2010). "Toward a science of service systems", in Handbook of service science, Springer, Boston, MA, pp157-19 
VARALDO R., DALLI D. (2011), "Le relazioni strategiche tra industria e distribuzione”, Sinergie, n. 61-62, pp. 255-294.

VARGO S.L., LUSCHR. F. (2004), "Evolving to a new dominant logic for marketing", Journal of Marketing, vol. 68, n. 1, pp. 1-17.

VARGO S.L., LUSCH R.F. (2008), "Service-dominant logic: continuing the evolution", Journal of the Academy of Marketing Science, vol. 36, n. 1, pp. 1-10.

VARGO S.L., MAGLIO P.P., AKAKA M.A. (2008), “On value and value co-creation: a service systems and service logic perspective", European Management Journal, vol. 26, n. 3, pp. 145-152.

VARGO S.L., LUSCH R.F. (2016), "Institutions and axioms: an extension and update of service-dominant logic", Journal of the Academy of Marketing Science, vol. 44, n. 5, pp. 5-23.

VILLAS-BOAS S.B. (2007), "Vertical relationships between manufacturers and retailers: inference with limited data", The Review of Economic Studies, vol. 74, n. 2, pp. 625-652.

VON BERTALANFFY L. (1968), General system theory, George Braziller, New York.

WOLFE M. (1955), “The concept of economic sectors", The Quarterly Journal of Economics, vol. 69, n. 3, pp. 402-420.

WOODLIFFE L. (2004), "Rethinking consumer disadvantage: the importance of qualitative research", International Journal of Retail and Distribution Management, vol. 32, n. 11, pp. 523-531.

WRIGLEY N., LOWE M. (1996), Retailing, consumption and capital: towards the new retail geography, Longman, London.

WRIGLEY N., LOWE M. (2002), Reading retail-geographical perspective on retailing and consumption spaces, Arnold, London.

\title{
Academic or professional position and contacts
}

\author{
Marcello Sansone \\ Associate Professor of Management \\ University of Cassino and Southern Lazio - Italy \\ e-mail: m.sansone@unicas.it \\ Roberto Bruni \\ Assistant Professor of Management \\ University of Cassino and Southern Lazio - Italy \\ e-mail: r.bruni@unicas.it

\section{Annarita Colamatteo} \\ $\mathrm{PhD}$ \\ University of Cassino and Southern Lazio - Italy \\ e-mail: a.colamatteo@unicas.it \\ Maria Anna Pagnanelli \\ PhD Student \\ pp.49-64 e-mail: mariaanna.pagnanelli@unicas.it
}

sinergie

italian journal of management
ISSN 0393-5108

DOI 10.7433/s107.2018.03 University of Cassino and Southern Lazio - Italy 